\title{
Kids on Board: Exploring the Choice Process and Vacation Needs of Asian Parents with Young Children in Resort Hotels
}

\author{
Khoo-Lattimore, C., Prayag, G., Cheah, B.L. \\ Accepted for Publication by the Journal of Hospitality Marketing and Management
}

\begin{abstract}
Vacation needs and the family decision-making processes are well researched in tourism. However, the role and influence of young children on parents' hotel choice remain sparsely researched in the context of Asian families. This study, hence, examines parents' choice criteria of resort hotels when holidaying with young children. Fifteen in-depth interviews with parents in Malaysia revealed five main themes: travel distance, quality of interactions, child-friendly amenities, safety, and family-oriented programs. Findings demonstrate not only the importance of providing specific hotel amenities and services such as baby toilet seats and bottle warmers to create a satisfactory holiday experience, but also that resorts can add to family quality-of-life by encouraging parent-child interactions through family-oriented activities. In this way, hotel resorts are building social capital. Marketing and managerial implications for family oriented resorts in Malaysia are offered.
\end{abstract}

Keywords: Family decision making, young children, resort hotel choice, family tourism, Malaysia 


\section{Introduction}

The family represents the dominant social group within which people spend their leisure time (Nichols \& Snepenger, 1988). Family oriented leisure activities generally contribute to positive interactions among family members (Lehto et al., 2012; Shaw, 1997). The family is also considered the most important social structure for vacation travel (Crompton, 1981), having positive effects on the psycho-social development of both young children and adolescents (Orthner et al., 1994). Family holidays are purported to strengthen social connectedness and positively contribute to social identity formation (Schanzel et al., 2012). Within the realm of consumer research, the family remains an important consumption unit that has been studied primarily for its decision-making processes, buying habits, and behavior (Epp \& Price, 2008; Filiatrault \& Ritchie, 1980; Lehto et al., 2012; Nanda et al., 2006). In the tourism field, past research investigates mainly the role of husband and wife in family vacation decision-making (Bronner \& de Hoog, 2008; Jenkins, 1978; Kim et al., 2010; Litvin et al., 2004). Few studies have investigated the family choice processes and behavior when children are holidaying with parents (Lehto et al., 2009; Nanda et al., 2006; Nickerson \& Jurowski, 2001; Schanzel et al., 2012; Small, 2008; Therkelsen, 2010; Thornton et al., 1997).

Among existing studies, contradictory evidence exists (e.g., Kim et al., 2010; Wang et al., 2004) on the level of influence of children on the vacation decision-making process. Early studies assert that children have some influence in the early stages of decision-making with respect to timing of holidays and choice of destination, accommodation and activities (Jenkins, 1979). However, children have no or little influence on the amount of money spent, and the final 
decision stages (Thornton et al., 1997; Wang et al., 2004). Children are seen as a passive component of the vacation (Howard \& Madrigal, 1990; Nickerson \& Jurowski, 2001; Thornton et al., 1997) and thought to have less decision making-power than parents (Beatty \& Talpade, 1994; Shaw, 1997). Traditionally, academics and the tourism industry have ignored children's influence on decision-making and the family holiday experience (Carr, 2006; Nickerson \& Jurowski, 2001; Schanzel et al., 2012; Thornton et al., 1997). Recent calls for better understanding of children's influence on the vacation decision-making process have been made by several scholars (Carr, 2006; Decrop, 2005; Kang \& Hsu, 2005; Nanda et al., 2006; Nickerson \& Jurowski, 2001; Therkelsen, 2010; Wang et al., 2004).

Within this context, the study explores one stage of the vacation choice process - resort hotel choice by parents when vacationing with young children (aged 12 or less). Hence, the main research question posed is: what are parents with young children seeking from resort hotels in their vacation decision-making process? The study contributes three fold to the tourism and hospitality literature. First, the study partially fulfills the observation of many scholars (e.g., Carr, 2006; Nanda et al., 2006; Nickerson \& Jurowski, 2001; Small, 2008) that the needs of children are absent in tourism research. Identifying the determinant factors for parents of hotel choice when vacationing with young children, can enable hotel marketers to better adapt their product and services to this segment. Second, existing studies fail to recognize the role of young children as social actors that can influence the vacation experience of parents (Schanzel et al., 2012; Therkelsen, 2010). This study explicitly considers that young children often co-create the resort-hotel experience of parents. Third, the family vacation decision-making literature is largely driven by the western family unit (e.g., Bronner \& de Hoog, 2008; Carr, 2006; Kang et al., 2005; Nickerson \& Jurowski, 2001; Obrador, 2012; Therkelsen, 2010). In comparison, the 
Asian family unit remains under researched (Kim et al., 2010; Wang et al., 2004), and some studies suggest (e.g., Ap, 2004; Wong, 1996) that Asians perceive and consume leisure and tourism services differently from their western counterparts. Given the World Tourism Organization's forecast that the leading tourism consumers by 2020 will be Asians, this study contributes to the much-needed literature on Asian family vacation decision-making processes.

\section{Literature Review}

\section{The Family Vacation Decision-Making Process}

Vacation experiences have been largely understood from the individual visitor perspective and rarely from the family point-of-view (Lehto et al., 2009). Within the family unit, leisure activities such as vacations can involve high expectations about the quality of the experience, the level of involvement, the time spent together, and the intensity of the interaction between family members can be higher than in other types of activity (Shaw, 1997). As such, there is a need to understand not only the family vacation decision processes, but also how individual members of the family may seek their own outcomes from the holiday experience. Often individual experiences and benefits sought from a vacation are intertwined and influenced by other significant traveling family members (Lehto et al., 2009).

Past studies have shown primarily three modes of decision-making for family vacation: husband-dominant, wife-dominant, and joint decision between husband and wife (Bronner \& de Hoog, 2008; Fodness, 1992; Jenkins, 1978; Kim et al., 2010; Litvin et al., 2004; Nanda et al., 2006). In the husband-dominant situation, the husband exerts primary influence over the purchase decision and actually makes the final choice. For example, husbands tend to dominate for the amount of money spent, length of vacation and price of the chosen accommodation 
(Filiatrault \& Ritchie, 1980). Wives tend to have more influence on individual vacation decisions at the information search stage and destination choice in families with children (Fodness, 1992). The joint-decision making process has become more popular over the years (Belch \& Willis, 2002; Bronner \& de Hoog, 2008; Kozak, 2010; Thornton et al., 1997) and results from either an autonomic process whereby the final decision is made by one partner but with considerable influence from the other or a syncratic process during which both parties contribute but neither dominates (Litvin et al., 2004). The two spouses may also engage in social power through compromising, bargaining, coercing or persuading one another that result in both parties making the decision (Davis \& Rigaux, 1974). The majority of studies on joint decision-making are, however, concentrated on western couples. Arguably, Asian customs and values such as belongingness, group conformity and reciprocity may impact on the way social power is exercised during a joint vacation decision-making process. Likewise, many travel products and sub decisions within the vacation choice process are not only negotiated between the parents but also influenced by children (Decrop, 2005; Howard \& Madrigal, 1990; Jenkins, 1979; Kang \& Hsu, 2005; Kozak, 2010; Nickerson \& Jurowski, 2001; Swinyard abd Sim, 1987; Wang et al., 2004). Children can have social power over parents' decision-making process and vacation choice (Flurry \& Burns, 2005).

\section{The Role of Children in the Vacation Choice Process}

The role of children in the vacation decision-making process is not without controversy. While some studies show that children have relatively little or no influence on the vacation decision process (e.g., Filiatrault \& Ritchie, 1980; Foxman et al., 1989), others show the contrary (e.g., Darley \& Lim, 1986; Howard \& Madrigal, 1990). The influence of children one the 
vacation decision-making process varies by type of product and services, family characteristics, family communication environment, age of child and stage of the decision making process (Kang et al., 2003; Kim et al., 2010; Nanda et al., 2006; Therkelsen, 2010). Although there is no agreement on parents' perceptions of the influence of children on the various vacation decisionmaking stages (Nanda et al., 2006), children typically influence types of activities (Jenkins, 1978; Wang et al., 2004), arrangement of meal times, need for sleep time (Thornton et al., 1997), and 'child friendly' marketing offers (Bronner \& de Hoog, 2008).

Some studies confirm increased decision influence with age (e.g., Howard \& Madrigal, 1990; Wang et al., 2004) while others show the contrary (e.g., Bronner \& de Hoog, 2008; Darley \& Lim, 1986. Increasing age may also bring an ability to negotiate thereby creating an expectation of flexibility or willingness to accept compromises not expected from younger children (Thornton et al., 1997). This is perhaps why little attention has been rendered to young children and their role in influencing family purchase decisions (Flurry, 2007) and vacation choice. More specifically, not much is known about parents' satisfaction with children-friendly amenities and facilities in resorts. Importantly, many of the existing studies on children's influence on vacation planning are based on western families. In contrast, the role children plays in the decision-making process of an Asian family may be different to a Western family. Asian families tend to have a more prevalent power on the lives of each member (Ap, 2004). Schutte and Ciarlante (1998) allude to the need for more research on the vacation needs of Asian parents with young children when they suggested that tourism plans for the Asian market should include amenities and services for family-oriented activities.

\section{Resort Hotel Choice Criteria for Parents with Young Children}


Resorts are a world of families and children (Carr, 2011) where typically different playing areas for each age group, special pools for young children, children clubs, special menus and even baby-sitting facilities are offered (Obrador, 2012). Usually families form the consumer base of many resorts that are typically designed for the young and family markets (Choi, Lehto, Brey, 2010). Resorts represent for many parents an intense family time devoted to the cultivation of togetherness and the strengthening of family bonds, thereby building social capital (Obrador, 2012; Schanzel et al., 2012). Family packaged holidays in resorts are often privileged stages for the display of love, unity and tenderness (Obrador, 2012), highlighting the importance of the accommodation unit for the family vacation experience.

Past studies confirm that hotel attributes directly impact choice and differentiate resorts (Chu \& Choi, 2000). Attributes such as cleanliness, location, room rate, room type, security, service quality, brand name and reputation are some of the most considered in resort choice (Atkinson, 1988; Chu \& Choi, 2000; Ekiz et al., 2012; McCleary et al., 1993; Tsai et al., 2011; Wong \& Chi-Yung, 2002). Surprisingly, tourism research has rarely taken notice of children and family holiday experiences in the context of mass tourism (Carr, 2011; Obrador, 2012). Families with children often have a different choice process for vacation and accommodation (Bronner \& de Hoog, 2008; Gram, 2005; Johns \& Gyimothy, 2002). Younger children can influence choice simply through their presence and their need for child care requirements but also through their ability to negotiate (Thornton et al., 1997). For example, the presence of younger children makes families more concerned about meal times, spend more time using swimming pools, and take part more often in beach activities (Thornton et al., 1997). Yet, these findings emanate from a western oriented concept of the family. 
Major differences exist between Asian and Western customers' hotel choice criteria and expectations as well as perceptions of service (Mattila, 2000; Tsai et al., 2011). The Asian style of service focuses on customization and personal attention rather than the efficiency, time saving and standardization so common in western service standards (Becker \& Murrmann, 1999). Asian customers place great emphasis on the quality of interactions between the employee and the customer in judging overall service quality (Mattila, 2000). The quality of interactions between front-line staff and guests, and the atmosphere created by the hospitality setting are important contributors to the hotel experience of the family market. Specifically in Malaysia, dimensions such as personalization of the service, a warm welcome, building a special relationship with guests throughout their stay, comfort and genuine service from staff contribute meaningfully to the service experience in four and five star hotels (Arrifin \& Maghzi, 2012). Yet, whether these attributes of a hotel are priorities for families with young children remain under researched. Lack of understanding of parents' needs from resorts may lead to poor service, inaccurate requests and errors in service delivery leading to negative experiences that unfavorably impact on customer satisfaction and future behavior (Heo et al., 2004). In fact, Brey (2010) cautions that resort customers "no longer want traditional leisure amenities but have additional expectations of what a resort experience is to encapsulate" (p.93).

\section{The Meaning of Leisure for Asian v/s Western Parents and Hotel Choice}

Recreation and leisure studies show that the western notion and meaning of leisure and vacation do not apply for many Asian families (Ap, 2004; Wong, 1996). Ap (2004), for example, highlighted how group engagement, learning and status elevation are particularly embraced by Asians on vacations. Earlier, Wong (1996) found that in Hong Kong, the most important factor driving local tourists to their main theme park was its educational element. These findings align 
with the value placed by Asian parents on education and self-improvement (Chao, 2000). Indeed, the majority of studies on Asian parenting are relatively recent and consistently show that Asian parents employ a more authoritarian style of parenting compared to Westerners (Chao, 1995; Gibson, 1988; Gorman, 1998). A prominent theme in Asian parenting has been on the control and strictness that Asian parents exercise on their children and their educational achievement. Many cross-cultural studies show that, at least in the American school system, Asian Americans do fare better (Fuligni, 1997; Mau, 1997; Okagaki \& Frensch, 1998). The parental concern over children's academic achievement in many Asian societies can be largely attributed to culture and beliefs. In the Asian context, children's education is regarded as the prime duty and obligation of parents. In fact, for many Asians, their value as parents is judged by how well their children perform in school (Chao, 1995; Wu \& Tseng, 1985). Specific Asian values impact parenting practices such as discipline, education and socialization, which in turn influence participation of Asian children in leisure activities (Shek, 1998), and the choice of leisure activities for children (Outley \& Floyd, 2002). Hence, the resort hotel choice for Asians may well be driven by other considerations such as eastern values and parenting beliefs that have rarely been accounted for in existing studies. In an Asian family, holiday activities could be seen more broadly as opportunities for their involvement in their children's education and greater participation in child development and learning. Arguably, resort choice may be driven to some extent by specific oriental values that Asian parents subscribe to.

\section{Methodology}

\section{The Qualitative Approach}


Past research on family vacation decision-making (e.g., Carr, 2006; Bronner \& de Hoog, 2008; Nichols \& Snepenger, 1988; Lehto et al., 2009; Litvin et al., 2004; Wang et al., 2008) has adopted mostly quantitative approaches. While these studies are certainly useful for advancing theoretical and managerial knowledge on decision-making styles, our objective is to yield rich and varied information in order to discover particular situations and atypical behaviors that may be of importance for theory development (Rubin \& Rubin, 1995). The use of qualitative methods in the study of family vacation decision-making processes is limited (Nanda et al., 2006; Therkelsen, 2010). Participants were selected on the premise that they would enable exploration of a particular aspect of the decision process (accommodation selection) and behavior related to the choice of activities and amenities relevant to young children.

\section{Sampling and Data Collection}

Driven by an interpretive paradigm and similar to the study of Noy (2008), a snowball sampling technique was used to identify specific couples who had been on a vacation with their young children in a resort in Malaysia. This sampling technique takes advantage of the "social dynamics of accessibility" (Noy, 2008, p. 338) and acknowledges the researchers' roles as parents with young children themselves. This researcher-researched interaction adopted by the snowball sampling technique reinforces the interpretive epistemology of how knowledge can be gained from what we already possess... within which we are immersed" (Noy, 2008, p.341). To ensure that the sample was not one-dimensional, several criteria were used to qualify respondents

for the interview. We first approached parents that we know had at least one child who is below 12 years of age. Age of the child is a critical factor in parents' vacation decision-making process (Bronner \& de Hoog, 2008; Darley \& Lim, 1986; Howard \& Madrigal, 1990; Nanda et al., 
2006). The cut-off age of 12 is mainly chosen for one reason. While past research on children as young tourists target the 8 to 14 year olds (Ritchie \& Uzabeaga, 2005; Seaton \& Bennett, 1996), hotels generally define children as those under the age of 12 and therefore benefits such as "Kids Eat Free" or "Kids Stay Free" are only limited for children under 12 years old only in Malaysia. We acknowledge that this group of children is not homogenous given that the needs of a 12 year old are dissimilar to those of a one year old. However, given the aim of the study, it is not unreasonable to use a wide age range for the children in sampling parents. Another criterion for inclusion was that the family must have taken a vacation together in the last one year. The number of interviewees was not pre-determined and the data saturation technique was followed (Patton, 2002). The study stopped after the fifteenth interview because repetition and redundancy of constructs were found from the fourteenth interview onwards.

There was no deliberate attempt to strike a balance between male and female participants. Our intention was to explore the vacation needs of families with young children in resorts rather than to examine how these needs varied as a function of gender. Studies specific to a holiday taking scenario have found that the joint decision process is generally typified as a compromise. Hence, spouses rely on conflict-avoiding heuristics to arrive at a choice (Kozak, 2010). Couples were asked to nominate the main decision-maker for their family vacations to be interviewed. Coincidentally, all 15 respondents are females and support the findings of previous studies on vacation decision-making. For example, Zalatan (1998) reported that pre-departure tasks, selection of a destination and the collection of information are areas where wives are highly involved. Recent studies confirm that women act as gatekeepers in household tourism decisionmaking. Specifically, Mottiar and Quinn (2004) revealed that women hold the decisions in the early stages of the vacation choice process, the initiation of the discussion, the collecting of the 
information and booking. Litvin et al (2004) found that two vacation decisions (selecting the holiday destination and choosing the holiday activities) that were traditionally joint have remained unchanged in recent years. These findings imply that the decision to interview only one spouse was as appropriate as interviewing couples together. The 15 female participants were aged between 29 and 41 years old, and have between one and three children under the age of 12 years. Two of the respondents have a diploma, nine have completed tertiary education and four have postgraduate qualifications. Except for two who were housewives, all respondents were in full-time employment and two revealed that they were chartered accountants. Together, the sample has 24 children under the age of 12. Of these, 15 are girls and 9 are boys. All participants have taken a family vacation with their children between March and November 2011.

\section{The Interview Protocol and Data Analysis}

Semi-structured interviews were conducted with parents of young children. The interview protocol consisted of three broad questions: (1) What are the five most important criteria in hotel selection when you are travelling with your children?; (2) What are the children's programs, activities and facilities that have you seen and experienced during your vacation?; (3) How can resorts make your vacation with kids more pleasurable? These questions were designed based on Maxwell (2005)'s guidelines that interview questions depend not only on the research questions but also the actual research situation and what works most effectively in that situation to give the needed data. The interviews were conducted in English given that the respondents are Malaysians proficient in the language, which is not uncommon in urban areas of Malaysia. Although the interviews started out with only three questions, probing was used to expand and clarify respondents' answers. Hence, the majority of the interviews lasted approximately ninety 
minutes. At times and with a few of the respondents, a second interview was carried out to further clarify answers they had given.

The interviews were transcribed according to Gubrium and Holstein's (2001)'s recommendations for data analysis. In order to gain familiarization with and understanding of the empirical material, an initial general analysis of the transcripts was conducted. A more in-depth analysis stage followed, where the transcripts were read over and over again. These stages of general and in-depth analysis can be likened to the open and axial coding espoused by Strauss and Corbin (1998). The general stage involves defining concepts and elements as mentioned by the respondents while the in-depth stage of analysis involves dividing and categorizing the whole empirical material into meaningful elements and groups before emergent themes or dimensions were identified (Creswell, 2007).

\section{Findings and Discussion}

The findings are aligned with the research questions posed earlier. First, the influence of young children on the vacation decision- making is outlined. Second, the most important criteria in resort choice are outlined.

\section{The Influence of Young Children in Family Vacation Decision Making}

While it was already clear at the sampling stage that wives were accountable for vacation decisions in families with young children, it was only after the analysis that we found young children exerting considerable influence in their parents' choice of holiday accommodation. Five key dimensions of family needs emerged from the transcripts and it is apparent that all five dimensions are strongly motivated by the caring necessities of young children and their intransigent schedules. These dimensions were travel distance, quality of interactions, child- 
friendly amenities, safety, and family-oriented programmes, all of which are expounded below using descriptive quotes given by respondents.

\section{Vacation Needs of Parents with Young Children}

\section{Travel Distance}

Although not surprising, all fifteen families experienced a domestic vacation in the last six months. In fact, most of the respondents quoted travel distance as a key determinant of their destination and hotel choice. It seems that parents are keen to enjoy a family holiday with their children in tow, but only to destinations (including hotels) that are not too far that will tire the children. Comments from respondents described how travel time should be: "mostly 3 to 4 hours, any longer the kids would not like it" (R3) and there should not be "much difference in time [zones]" (R2). Travel distance was in fact the main reason why parents had chosen to holiday in a specific destination. The finding reflects the importance attached to the holiday itself and the constraint that travel time can impose on the holiday experience of families with young children. This is consistent with the findings from a Malaysian study suggesting that $75 \%$ of respondents preferred a local destination when travelling for holiday purposes (Segumpan et al., 2008). We acknowledge that parents' income factor could have influenced this inclination for domestic vacation destinations and although in hindsight we should have asked for information on income level, we also understand that the amount of money set aside for family vacations may not be proportional to household income. However, we do know that two respondents who have cited short travel distance as a prerequisite of destination choice were in well-paying positions as chartered accountants in Malaysia. Therefore, we have evidence to believe that in at least these 
two respondents, the need for short distance travel was due to the young children in the travel party rather than to economic limitations.

\section{Quality of Interactions}

One of the most dominant statements that came from the majority of the participants is the need for quality interactions between hotel staff and children. One participant (R13) provided a somewhat rudimentary definition of what constitutes good quality interactions: "having staff members who are good with kids, [they] greet kids by name, smile, and make kids feel included rather than ignored." She elaborated further on how her own experience was negatively affected by the way hotel employees interacted with children. The lack of personalization or warmth towards children is a source of dissatisfaction for parents. The need for service personalization common for adult consumers is often ignored in service delivery to children. The same respondent also wanted hotel employees "to be more friendly and approachable towards the kids. For example, check in staff should greet kids and offer a candy or balloons" to make them feel welcomed. According to her, this is the acceptable level of service. Another respondent (R2) added that quality interactions are related to staff "who knows how to treat children when they are hurt [and] pacifies them when they are throwing tantrums". This level of service would significantly add to her family vacation but also reflect the need for parents to spend time away from children for an enjoyable holiday. The finding provides insights for hotels and resorts targeting families on the quality of interactions expected by customers and provide guidelines for staff training. Staff members need to be trained and qualified in basic aspects of early childhood education to increase both child and parent holiday satisfaction. 
Another respondent (R12) recounted her positive experience of the resort due to the interaction between a hotel staff and her child: "during our stay at Pangkor Laut, the hotel staff took care of my son while we dined in peace. They played with him and took him away for fish feeding at the hotel pond." This reinforces the idea of parents valuing time spent away from children. One respondent (R5) echoed this need for quality interactions in the context of staff knowledge. "Knowledgeable staff can make suggestions once they find out that there are children on board. Even if they don't have in house programmes, they can make recommendations on suitable children attractions, theaters, plays that are in town" (R8). Not only the need for service personalization based on children's age and interests is emphasized by parents but also the importance of hotel staff to be empowered with information and knowledge on children. The importance of staff knowledge has been stressed in studies on retailing (e.g., Lockshin \& Kahrimanis, 1998; Merrilees \& Miller, 2001) and tourism (e.g., Chu \& Choi, 2000; Tsai et al., 2011), but not sufficiently enough in family tourism studies. The findings may also suggest the need hotel managers to rethink about job design and accountability of front-line employees who serve parents and children.

\section{Child-Friendly Amenities}

Respondents concur that hotels and resorts need to pay more attention on the services provided to families with young children. While they appreciate that some hotels deliberately target families by building facilities in their premises for children such as play centres, swimming pools and water slides, lodging establishments have too often forgotten to provide the much needed practical and human aspects of hospitality for guests with young children. Respondents typically emphasised the need for "family parks", "big enough rooms", and "kids' meals" to enhance their holiday experience. Where meals are concerned for example, parents 
with young children call for "delicious children food" (R5 and R12) with kids' cutlery (R1) and "kids-friendly meals and not deep-fried nuggets or French fries. Hotels have to offer healthy food to children, including fruit slices, muesli bars, spaghetti, fun vegetables, amongst others" (R13). The quotes suggest the need for quality and healthy food. In relation to food and meal times, families would also like hoteliers to provide them with some less tangible services for example, in-room service for families with kids (R1). Despite the holiday being a time for social connectedness and social identity formation for the family (Schanzel et al., 2012), meal times are often stressful for parents with young children which detracts from such goals. Hotels have yet to cater for making meal times a pleasurable experience for parents in a way that it contributes to the reinforcement of bonds between parents and kids through family meals. In almost all cases, meal times contribute significantly to perceptions of inadequate service by hoteliers.

Besides food, respondents feel that hotel services should cater to "parents' request for inroom items related to child[ren]" (R2) such as baby toilet seats, bottle warmers, sterilisers, diapers, swim diapers, wipes, sunscreen for children, toddler snacks and drinks. While the swimming pools top the list for the most needed facility for young children, parents say hotels will do well to provide additional child-friendly pool service with the provision of "heated pool" (R2) and "pool toys, floats and perhaps even inflatable water slides, bucket, spade, all for rent or free of charge, so that parents don't have to bring these" (R13). The needs of families with young children on vacation can be conceptualised as ideas for contemporary services that hotels can provide to add to their guests' experiences. A recent study by Segumpan et al. (2008) ranked twenty five factors associated with family tourism in Malaysia. Amongst the identified factors are available facilities, physical and mental relaxation. However, the study fails to provide further details as to what these factors mean. Our findings provide a detailed description of the 
intangible experiential qualities families seek in their accommodation when they travel with young children.

\section{Safety}

Parents with young children want staff members who can not only relate to their children but also establish a stimulating yet safe environment for the young holidaymakers. Indeed, the issue of safety is one which was emphasized heavily in the dimension of interactions and its quality. In fact, many of the parents are not content with resorts providing childcare facilities without staff members having the appropriate qualifications. One respondent's (R4) statement is representative of parents' concern for "safe" (R2), "reliable" (R6), "qualified" (R13) and "responsible" (R14) staff. The respondent (R4) further mentioned that while she will take her children to the playrooms provided by resorts, "I usually don't leave my children with the childcare" because "childcare personnel are not well trained." Relatedly, safety becomes an issue yet again when discussions centered on the pool and respondents wanted to see qualified lifeguards on duty, "as in a split of a second, a child may drown!!" (R3). Other more contemporary needs that surfaced from the interviews include express check-in for families with young children and valet parking where parents:

can pick up my child from the car seat and drop the key to the jockey or concierge, they will [then] load my luggage by the reception desk, and I just need to present my passport or NRIC (national registration identity card) to them, they have the room key and paperwork ready for me to sign, and inform me the room is ready, rather than waiting...(R5) 
As previous studies on tourism and families have not before focused on the needs of parents with young children, this newly uncovered dimension is elemental in moving forward a new marketing agenda for hotels and resorts catering to the family market. The services mentioned by the respondents pinpoint to the need for hotels to provide additional services that may be part of an augmented service that differentiates and positions one resort from another. This finding left us wondering if safety is a dimension only pertinent to parents in the Asian context, given that safety is more of a concern in developing rather than developed countries.

\section{Family-Oriented Programmes (and its Relevance to Asian Parents)}

Given the caring requirements of young children on holiday, the majority of the respondents commented on the availability of the children programmes organised by hotels and resorts, and their associated children clubs. To the researchers' surprise, many parents do not regard these programmes favourably. The main reason for their disapproval was traced back to the lack of thought that went into the implementation strategies of the programmes. First of all, children programmes in hotels and resorts tend to follow a set schedule which families find hard to keep up with. One respondent (R1) explains, "we do things as a family most of the time and we do not like to follow schedules." For this reason, respondents echoed the sentiment that "I would prefer to create our own programmes and activities" (R5). This finding is not surprising considering recent studies by Backer and Schanzel (2012) and Plog (2005) where more than half of their respondents cited having no schedule as their reason for taking a family holiday. This finding has revealed that by providing presumably "fun" family-associated programmes, hotels have actually added to the stress of holiday experiences for families with young children. One important parental motivator for holidays is relaxation (Schanzel et al., 2012) and clearly, scheduled programmes and activities for children may detract from this. 
Another reason for the respondents' disapproval towards hotel-run programmes is that most, if not all, children-based activities in hotels and resorts exclude parents from participating. This dismisses the very core family experiential needs - the need to enhance family relationships, strengthen family ties and share common experiences (Davidson, 1996; Lehto et al., 2009; Schanzel et al., 2012). Protests to the way children activities are scheduled are exemplified with a respondent's (R4) complaint:

"... if we go on holiday together, I'd like to do things together with my children.

Otherwise, I would go to vacations without kids. So children activities that are provided by the hotel are not very attractive to me."

This finding actually accentuates the duality in the family holiday experience whereby parents desire personal space (Gram, 2005) but also want to spend quality time with children. The finding also supports past researchers' call to understand family vacation as a consumption unit and to stop treating children and adult needs as two entities (Lehto et al, 2009). Activities and programmes should be designed to provide opportunities for both parents and children to engage and interact.

Finally, the holiday activities that parents seek from hotels for their children are more educational rather than hedonistic. Respondents suggested that they would like to see more educational-related programmes which include "things that kids don't get to do on a daily basis" (R4). Perhaps this is directly associated with the demographic of the parents in this study who in majority, have professional careers. Nevertheless, it is apparent that the activities planned by hotels and resorts targeting families have not kept up with the new trends in child's play. Some of the examples respondents gave are programmes and activities that link to new skill development "so that children gain positive knowledge during their vacation" (R12). Parents 
wanted activities that provide opportunities for children to not only to play but also to explore and discover. They expressed experiential "play" needs such as swimming class (R3); pony riding (R5); cooking, baking and cake design (R3 and R7); painting, art and craft (R2, R7, R11 and R13); drama, storytelling and muppet shows (R2, R7, R11 and R12), drawing and coloring (R11 and R13); educational trip to places of attraction nearby (R14); rock climbing and indoor gym (R15); dress-up play, simple science-related play like collecting leaves and bugs, and anything outdoorsy, rabbit and other animal feeding along with lessons on these animals (R13). These requests could well be linked to earlier discussion on Asian values and the importance Asian parents place on academic and intellectual achievement. These findings confirm the notion that family tourists' behaviour is shaped by socio-cultural as well as personal values that are present in the home (Carr, 2002), rather than a complete departure from what is routine. Upon closer consideration, the researchers observe that these are also activities which can easily include parent-participation, and addresses the issue of parent-child activities being treated as separate entities. Perhaps it is the non-existent of these constructive play activities that bond the parent-child relationship in hotels and resorts that push families to go out:

"sightseeing at the local attraction...[which are]what we like to teach her and what she enjoys...that we think is more benefits for her and what she is more interested rather than resort's playroom (R5).

\section{Managerial Implications}

Similar to other studies (e.g., Fodness, 1992; Nanda et al., 2006; Thornton et al., 2007; Wang et al., 2004; Zalatan, 1998), our findings indicate a wife dominant decision making process for holidays among Malaysian households. This typically contradicts the western 
perspective of joint-decision making for holidays that involve children (Bronner \& de Hoog, 2008). Therefore, there is a need for Malaysian-based resorts to reconsider current advertising practices - family holiday packages are mainly advertised in mainstream newspapers and business magazines that are masculine in nature. Perhaps materials and channels for resort marketing should be better aimed at a niche female sub-segment of wives and mothers. While safety is an important criteria of hotel choice for Asian holiday makers in general (Arrifin \& Maghzi, 2012; Chu \& Choi, 2000; Ekiz et al., 2012; Tsai et al., 2011), this attribute is a critical determinant of choice for families with young children. Marketing materials for resort-hotels should highlight the facets of the hotel infrastructure that create a safe environment for children to attract this segment.

In an Asian setting, the lack of children friendly services and amenities, may cause stress that dampens the holiday experience. As such, resorts may need to rethink their service offer to families with young children. Particularly, room design and in room amenities such as baby toilet seats and bottle warmers are considered as basic requirements rather than augmented service. Resorts offering such amenities and quality food to children are more likely to be selected as a holiday base than resorts offering generic facilities and amenities.

Besides tangible facilities such as swimming pools and children clubs, the intangible aspects of service delivery also matter to families with young children. Particularly, the quality of interactions between staff and children is important to parents. Previous studies on the Malaysian hotel experience (Ariffin \& Maghzi, 2012) confirm that service personalization, comfort, and warm welcome are important to customers. Our findings go further and suggest that these experiences need to be extended to children for a satisfactory holiday experience. The quality of interactions between staff and children is a determinant of parents' satisfaction. While 
family vacations are thought to enhance family well-being in many ways through socialization in a new setting, freedom from routines roles and responsibilities, and family interactions that contribute to family bonding (Lehto et al., 2009), our findings suggest that such goals are only achievable when the hotel infrastructure and service, including staff attitude and behavior, create an environment that facilitates child-parent interactions.

The findings also have implications for the type of activities and holiday programmes offered to both children and parents staying in resorts as well as the general holiday experience of families. Existing offers are unsatisfactory to parents primarily because they are scheduled and are not conducive to family bonding. Perhaps a solution to this is to revamp existing programmes to incorporate elements of flexibility, education, and parent-participation. The marketing literature calls for co-creation of the service experience (Gronroos \& Ravald, 2011). Hotel experiences should therefore be designed by parents, hoteliers and children in order to enhance the value proposition. The types of activities, facilities and amenities offered to the family market, including entertainment facilities should facilitate staff, parent and children interactions. The emphasis on academic achievement for Asian parents is reflected in the way they experience holidays. Holiday activities are seen more broadly as opportunities for their involvement in their children's education and for child development and learning. Hence, there is a need for resorts to offer stimulating programmes and activities that enhance children's desires to play and learn. Overall, these findings act as a call for industry practitioners to reconsider their function, to not only provide accommodation, but also improve the quality of family life for their guests, especially those with young children.

Finally, our findings highlight the importance of travel distance in the resort selection process for parents with young children. Hotel developers seeking to attract the family market 
should therefore consider this criterion in deciding on the geographical location of their hotel and use this criterion in the communication strategy.

\section{Conclusion}

In conclusion, the contribution of this study to the tourism and hospitality literature is primarily centered on the experiential needs of Asian parents with young children and their resort-hotel choice criteria. The paper contributes to existing knowledge by describing in detail the specific dimensions that will add to family vacations. The presence and needs of young children are acknowledged as a variable to potentially influence Asian parents' choice of vacation and accommodation. This provides further insights into the influence of children on the demand for specific hospitality elements in a resort setting.

However, the study is not without limitations. First, the study is based on a qualitative research design and the propositions, attitudes and behavior found in this study must be confirmed in a quantitative study. Second, the study incorporates the views of wives mainly and therefore do not include their husbands' nor the children's perspective. Future scholars should investigate in depth what fathers think their vacation needs as a family are as it would be interesting to see if these are consistent with those voiced by their wives. We also recommend that future studies should integrate young children's perspective, particularly when research has shown children to be influential in family decision-making (Jenkins, 1979; Carr, 2006; Nickerson \& Jurowski, 2001). Insights into what children would enjoy during their family vacation may provide resorts with another set of fundamental guidelines to reveal specific items and areas that families with young children are really looking for. Our own current ongoing research project initiates conversations with children under the age of twelve, this we aim to 
research and report back in subsequent work. Finally, this study was mainly confined to Malaysian parents on vacations with their young children in tow. The age range of the children referred to in this study is wide at 12 years and despite this diversity, it is expected that the needs of families with infants are different from those with preschoolers. Therefore, future work could take on a more micro perspective by focusing on families with young children of specific age groups. Also, research can be carried out on other Asian and Western parents with young children arriving in Malaysia to strengthen advocacy for more educational-related programmes to be implemented in family-focused resorts.

\section{References}

Ap, J. (2004). Intercultural behaviour: Glimpses of leisure from an Asian perspective. In, Klaus Weiermair, Christine Mathies (Eds). The Tourism and Leisure Industry: Shaping the Future. Binghampton, New York, Haworth Hospitality Press, 123-134

Arrifin, A.A.M., \& Maghzi, A. (2012). A preliminary study on customer expectations of hotel hospitality: influences of personal and hotel factors. International Journal of Hospitality Management, 31(1), 191-198.

Atkinson, A. (1988). Answering the eternal question: what does the customer want? The Cornell Hotel and Restaurant Administration Quarterly, 29(2), 12-14.

Backer, E., Schanzel, H. (2012). The Stress of the Family Holiday. In, Heike Schanzel, Ian Yeoman, Elisa Backer (Eds). Family Tourism: Multidisciplinary Perspectives. Bristol, Channel View Publications, $105-124$.

Beatty, S.E., \& Talpade, S. (1994). Adolescent influence in family decision making. Journal of Consumer Research, 21(2), 332-341. 
Becker, C., \& Murrmann, S.K. (1999). The effect of cultural orientation on the service timing preferences of customers in casual dining operations: an exploratory study. International Journal of Hospitality Management, 18(1), 59-65.

Belch, M.A., \& Willis, L.A. (2002). Family decision at the turn of the century: has the changing structure of households impacted the family decision-making process? Journal of Consumer Behavior, 2(2), 111-124.

Brey, E.T. (2010). Developing a better understanding of resort management. Journal of Hospitality Marketing and Management, 20(1), 79-102.

Bronner, F., \& de Hoog, R. (2008). Agreement and disagreement in family vacation decisionmaking. Tourism Management, 29(5), 967-979.

Carr, N. (2002). The tourism-leisure behavioural continuum. Annals of Tourism Research, 29(4), 972-986.

Carr, N. (2006). A comparison of adolescents' and parents' holiday motivations and desires. Tourism \& Hospitality Research, 6(2), 129-142.

Carr, N. (2011). Children's and Families' Holiday Experiences. London: Taylor \& Francis

Chao, R. (1996). Chinese and European Americans mothers' beliefs about the role of parenting in children's school success. Journal of Cross-cultural Psychology, 27(4), 403-423.

Chao, R. \& Tseng, V. (2002). Parenting of Asians. In M. H. Bornstein (Series Ed.), Handbook of parenting: Vol. 4 Social conditions and applied parenting (2nd ed., pp59-93). Mahwah, New Jersey: Lawrence Erlbaum Associates

Chao, R. K. (1995). Chinese and European American cultural models of the self-reflected in mothers' childrearing beliefs. Ethos, 23(3), 328-354.

Chao, R.K. (2000). The parenting of immigrant Chinese and European American mothers: Relations between parenting styles, socialization goals, and parental practices. Journal of Applied Developmental Psychology, 21(2), 233-248.

Choi, H.Y., Lehto, X., Brey, E.T. (2010). Investigating resort loyalty: Impacts of the family life cycle. Journal of Hospitality Marketing and Management, 20 (1), 121-141.

Chu, R.K.S., \& Choi, T. (2000). An importance performance analysis of hotel selection factors in Hong Kong hotel industry: a comparison of business and leisure travelers. Tourism Management, 21(4), 363-377.

Creswell, J. W. (2007). Qualitative Inquiry and Research Design: Choosing among Five Approaches (2nd ed.). London: Sage. 
Crompton, J.L. (1981). Dimensions of the social group role in pleasure vacations. Annals of Tourism Research, 8(4), 550-567.

Darley, W.K., \& Lim, J.S. (1986). Family decision making in leisure time activities: an exploratory investigation of the impact of locus of control, child age influence factor and parental type on perceived child influence. In R.J. Lutz (Ed.), Advances in Consumer Research, 13 (pp. 370-374), Provo: Utah, Association for Consumer Research.

Davidson P. The holiday and work experiences of women with young children, Leisure Studies, 15(2), 89-103

Davis, H.L., \& Rigaux, B.P. (1974). Perceptions of marital roles in joint decision processes. Journal of Consumer Research, 1(2), 43-50.

Decrop, A. (2005). Group process in vacation decision making. Journal of Travel \& Tourism Marketing, 18(3), 23-26.

Ekiz, E.H., Khoo-Lattimore, C., Memarzadeh, F (2012). Air the Anger: Investigating Online Complaints on Luxury Hotels, Journal of Hospitality and Tourism Technology, 3(2), 96-106.

Epp, A.M., \& Price, L.L. (2008). Family identity: a famework of identity interplay in consumption practices. Journal of Consumer Research, 35(1), 50-70.

Filiatrault, P., \& Ritchie, J.B.R. (1980). Joint purchasing decisions: a comparison of influence structure in family and couple decision making units. Journal of Consumer Research, 7(2), 131140.

Flurry, L. A. (2007). Children's influence in family decision-making: Examining the impact of the changing American family. Journal of Business Research, 60(4), 322-330

Flurry, L.A., Burns, A.C. (2005). Children's influence in purchase decisions: a social power theory approach. Journal of Business Research, 58, 593-601.

Fodness, D. (1992). The impact of family life cycle on the vacation decision-making process. Journal of Travel Research, 31(2), 8-13.

Foxman, E.R., Tansuhaj, P.S., \& Ekstrom, K.M. (1989). Family members' perceptions of adolescents' influence in family decision making. Journal of Consumer Research, 15(4), 482-491.

Fuligni, A. J. (1997). The academic achievement of adolescents from immigrant families: The roles of family background,attitudes, and behavior. Child Development, 68(2), 351-363.

Gibson, M. A. (1988). Accommodation without assimilation: Sikh Immigrants in an American High School. NY: Cornell University Press. 
Gorman, J. C. (1998). Parenting attitudes and practices of immigrant Chinese mothers of adolescents. Family Relations, 47(1), 73-80.

Gubrium, J. A., \& Holstein, J. A. (2001). Handbook of Interview Research: Context and Method. Thousand Oaks, California: Sage.

Gram, M. (2005). Family holidays: a qualitative analysis of family holiday experiences. Scandinavian Journal of Hospitality \& Tourism, 5(1), 2-22

Grönroos, Christian \& Ravald, Annika (2011) : Service as business logic: implications for value creation and marketing. Journal of Service Management, 22 (1), 5-22

Hao, L., and Bonstead-Bruns, M. (1998). Parent-child differences in educational expectations and the academic achievement of immigrant and native students. Sociology of Education, 71(3), $175-198$.

Heo, J.K., Jogaratnam, G., \& Buchanan, P. (2004). Customer focused adaptation in New York City hotels: exploring the perceptions of Japanese and Korean travelers. Tourism Management, 23(1), 39-53.

Howard, M. (2012). Family Tourism: Multidisciplinary Perspectives. Channel View Publications : Bristol.

Howard, D.R., \& Madrigal, R. (1990). Who makes the decision: the parent or child? The perceived influence of parents or children on the purchase of recreation services. Journal of Leisure Research, 22(3), 244-258.

Jenkins, R.L. (1978). Family vacation decision making. Journal of Travel Research, 16(4), $2-7$.

Jenkins, R.L. (1979). The influence of children in family decision-making: parents' perceptions. Advances in Consumer Research, 6, 413-418

Johns, N., \& Gyimothy, S. (2002). Mythologies of a theme park: an icon of modern family life. Journal of Vacation Marketing, 8(4), 320-331.

Kang, S., \& Hsu, C. (2005). Dyadic consensus on family vacation destination selection. Tourism Management, 26(4), 571-582.

Kang, S.K., Hsu, C.H.C., \& Wolfe, K. (2003). Family traveler segmentation by vacation decision-making patterns. Journal of Hospitality \& Tourism Research, 27(4), 448-469.

Kim, S.S., Choi, S., Argusa, J., Wang, K.C., \& Kim, Y. (2010). The role of family decision makers in festival tourism. International Journal of Hospitality Management, 2(2), 308-318. 
Knutson, B.J. (1988). Frequent travelers: making them happy and bring them back. Cornell Hotel \& Restaurant Administration Quarterly, 29(1), 83-87.

Kozak, M. (2010). Holiday taking decisions- the role of spouses. Tourism Management, 31(4), 489-494.

Lehto, X.Y., Choi, S., Lin, Y.C., \& MacDermind, S.M. (2009). Vacation and family functioning. Annals of Tourism Research, 36(3), 459-479.

Lehto, X.Y., Lin, Y.C., \& Choi, S. (2012). Family vacation activities and family cohesion. Journal of Travel \& Tourism Marketing, 29(8), 835-850.

Litvin, S.W., Xu, G., \& Kang, S.K. (2004). Spousal vacation-buying decision making revisited across time and place. Journal of Travel Research, 43(2), 193-198.

Lockshin, L. \& P. Kahrimanis (1998). Consumer Evaluation of Retail Wine Stores. Journal of Wine Research, 9(3), 173-184.

Mattila, A. (2000). The impact of culture and gender on customer evaluations of service encounters. Journal of Hospitality \& Tourism Research, 24(2), 263-273.

Mau,W. (1997). Parental influences on the high school students' academic achievement: A comparison of Asian immigrants, Asian Americans, and White Americans. Psychology in the Schools, 34, 267-277.

Maxwell, J.A. (2005). Qualitative Research Design: An Interactive Approach. Thousand Oaks: Sage.

McCleary, K.W., Weaver, P.A., \& Hutchinson, J.C. (1993). Hotel selection factors as they relate to business travel situations. Journal of Travel Research, 32(2), 42-48.

Merrilees, B. and Miller, D. (2001), Superstore interactivity: a new self-service paradigm of retail service?, International Journal of Retail \& Distribution Management, 29 (8\&9), 379 -389.

Mintel (2004). Family Holidays, Leisure Intelligence, June. London: Mintel International Group.

Murphy, J.A. (1996). Retail Banking. In Francis Buttle (Ed.), Relationship Marketing: Theory and Practice (pp. 74-101). London : Sage.

Nanda, D., Hu, C., \& Bai, B. (2006). Exploring family roles in purchasing decisions during vacation planning. Journal of Travel \& Tourism Marketing, 20 (3), 107-125.

Nichols, C.A., \& Snepenger, J.D. (1988). Family decision making and tourism behavior and attitudes. Journal of Travel Research, 26(4), 2-6. 
Nickerson, N.P., \& Jurowski, C. (2001). The influence of children on vacation travel patterns. Journal of Vacation Marketing, 7(1), 19-30.

Obrador, P. (2012). The place of the family in tourism research: domesticity and thick sociality by the pool. Annals of Tourism Research, 39(1), 401-420.

Okagaki, L. F., and Frensch, P. A. (1998). Parenting and children's school achievement: A multiethnic perspective. American Educational Research Journal, 35, 123-144.

Orthner, D.K., Barnett-Morris, L., \& Mancini, J.A. (1994). Leisure and family over the life cycle. In L.L. L'Abate (Ed.), Handbook of Developmental Family Psychology \& Psychopathology (pp. 176-201). New York: Wiley Thomas.

Outley, C.W., \& Floyd, M.F. (2002). The home they live in: inner city's children's views on the influence of parenting strategies on their leisure behavior. Leisure Sciences, 24(2), 161-179.

Patton, M.Q. (2002). Qualitative Research and Evaluation Methods. Thousand Oaks, California : Sage.

Plog, S. (2005). Targeting segments: More important than ever in the travel industry. In W. Teobald (ed.), Global Tourism (3 ${ }^{\text {rd }}$ Edition) (pp. 271-293). Sydney: Elsevier.

Ritchie, B., \& Uzabeaga, S. (2005) Discover What It Means to be Australian in your national capital: Size and effect of school excursions to the national capital. Canberra: Centre for Tourism, University of Canberra, National Capital Educational Tourism Project.

Rubin, H.J., \& Rubin, I.S. (1995). Qualitative Interviewing: The Art of Hearing Data. Thousand Oaks: Sage.

Schanzel, H., Yeoman, I., \& Backer, E. (2012). Family Tourism: Multidisciplinary Perspectives. Bristol, UK: Channel View Publications.

Schutte, H., Ciarlante, D. (1998). Consumer research in Asia. London: MacMillan.

Shaw, S.M. (1997). Controversies and contradictions in family leisure: an analysis of conflicting paradigms. Journal of Leisure Research, 29(1), 98-112.

Shaw, S.M. (2008). Family leisure and changing ideologies of parenthood. Sociology Compass, 2(2), 688-703.

Seaton, A.V., Bennett, M.M. (1996) Marketing Tourism Products. London: Thomson Business Press.

Segumpan, R.G., Abu Zahari, J.S., \& Jamaluddin, M.M. (2008). Tourism among families in Northern Peninsular Malaysia. Asia- Pacific Social Science Review, 8(2), 129-139. 
Shek, D.T.L. (1998). Adolescents' perceptions of paternal and maternal parenting styles in a Chinese context. Journal of Psychology, 132(5), 527-537.

Small, J. (2008). The absence of childhood in tourism studies. Annals of Tourism Research, 35(3), 772-789.

Strauss, A., Corbin, J. (1998). Basics of Qualitative Research: Techniques and Procedures for Developing Grounded Theory, $2^{\text {nd }}$ edn. California: Sage Publications.

Swinyard, W.R., Sim, C.P. (1987). Perception of children's influence on family decision processes. Journal of Consumer Marketing, 4(1), 25-38.

Therkelsen, A. (2010). Deciding on family holidays- role distribution and strategies in use. Journal of Travel \& Tourism Marketing, 27(8), 765-779.

Thornton, P.R., Shaw, G., \& Williams, A.M. (1997). Tourist group holiday decision-making and behaviour: the influence of children. Tourism Management, 18(5), 287-297.

Tsai, H., Yeung, S., \& Yim, P.H.L. (2011). Hotel selection criteria used by mainland Chinese and foreign individual travelers to Hong Kong. Journal of Travel \& Tourism Marketing, 12(3), 252-267.

Wang, K.C., Hsieh, A.T., Yeh, Y.C., \& Tsai, C.W. (2004). Who is the decision-maker: the parents or the child in group package tours? Tourism Management, 25(2), 183-194.

Wong, E. (1996). A study of educational value in a theme park with reference to a case study of Ocean Park. Unpublished final year dissertation, Hong Kong Polytechnic University.

Wong, K.K.F., \& Chi-Yung, L. (2002). Predicting hotel choice decisions and segmenting hotel consumers: a comparative assessment of a recent consumer based approach. Journal of Travel \& Tourism Marketing, 11(1), 17-33.

Wu, D. Y. H., and Tseng, W. S. (1985). Introduction: The characteristics of Chinese culture. In W. S. Tseng \& D. Wu (Eds.), Chinese culture and mental health (pp. 113-134). Orlando, FL: Academic Press.

Zalatan, A. (1998). Wives' involvement in tourism decision processes. Annals of Tourism Research, 25 (4), 890-903. 